\title{
Determinaton of physiological ripening time based on change in physicochemical characteristics during fruit development of 'Hanareum' pear ( $P$. pyrifolia Nakai)
}

\author{
Yoon-Kyeong Kim ${ }^{1 *}$, KyungHo Won ${ }^{1}$, In Bog Lee ${ }^{2}$, ByulHaNa Lee ${ }^{1}$, Ug-Yong Lee ${ }^{1}$, \\ Sam-Seok Kang ${ }^{1}$, Il-Sheob Shin ${ }^{3}$, Hae Won Jeong ${ }^{1}$ \\ ${ }^{1}$ Pear Research Institute, National Institute of Horticultural and Herbal Science, RDA Naju 58216, Korea \\ ${ }^{2}$ Horticultural and Herbal Crop Environment Division, National Institute of Horticultural and Herbal Science, \\ RDA, Wanju 55365, Korea \\ ${ }^{3}$ Postharvest Research Division, National Institute of Horticultural and Herbal Science, RDA, Wanju 55365, Korea
}

\section{생육단계별 이화학 특성변화에 근거한 ‘한아름' 배의 적숙기 판정}

\author{
김윤경 ${ }^{*} \cdot$ 원경호 $^{1} \cdot$ 이인복 ${ }^{2} \cdot$ 이별하나 ${ }^{1} \cdot$ 이욱용 $^{1} \cdot$ 강삼석 $^{1} \cdot$ 신일섭 $^{3} \cdot$ 정해원 $^{1}$ \\ ${ }^{1}$ 국립원예특작과학원 배연구소, ${ }^{2}$ 국립원예특작과학원 원예특작환경과, ${ }^{3}$ 국립원예특작과학원 저장유통과
}

\begin{abstract}
This study was conducted to determine the optimal physiological ripening time and suggest a reasonable harvest time indicator by analyzing the relationship between change in physicochemical characteristics and the sugar composition change patterns during development of 'Hanareum' fruit from 54 days after full bloom (DAFB) to 130 DAFB. The weight of fruits from 96 to 115 DAFB rapidly increased and then became gentle showing a typical sigmoidal curve. Flesh hardness decreased steadily after 96 DAFB; there was no significant difference in flesh hardness for 115, 125 and 130 DAFB fruits. The starch content began to reduce around the core for 119 DAFB. Moreover, sucrose and fructose contents started to increase with fruit development; however, the sucrose content continuously increased, whereas the fructose content started to decrease for 110 DAFB. Fruits of 125 and 130 DAFB did not show coloration according to the iodine test. Based on these results, it was estimated that the optimal physiological ripening time of 'Hanareum' was between 119 and 125 DAFB. The results of correlation analysis between fruit development change and sugar composition change patterns of fruits of 'Hanareum' showed that there was a strong linear relationship. Correlation coefficient between the sucrose/fructose (S/F) ratio and flesh hardness is $-\mathbf{0 . 5 7}$, between $\mathrm{S} / \mathrm{F}$ ratio and iodine test results is $\mathbf{0 . 8 0}$. Namely, $\mathrm{S} / \mathrm{F}$ ratio is possible to use for harvest time determination indicator and the point of $S / F$ ratio of $0.9-1.1$ was considered to be ideal for the determination of the optimal physiological ripening time at which starch completely degrades.
\end{abstract}

Key words : fructose, harvest time, iodine, starch, sucrose

서 론

*Corresponding author. E-mail : horti8992@korea.kr

Phone : 82-61-330-1541, Fax : 82-61-330-1533

Received 08 February 2019; Revised 02 April 2019; Accepted 01 June 2019.

Copyright (c) The Korean Society of Food Preservation. All rights reserved.
중생종 ‘신고'가 국내 전체 배 재배면적 $83 \%$ 를 점유하는 실태는 생산 및 소비가 편중되어 배 산업의 안정적인 발전 에 걸림돌이 되는 것으로 전망되고 있다. 이에 다양한 숙기 의 품종 재배를 대안으로 제시하고 있으며 배의 소비도 제수 및 선물용으로는 대과를, 자가 소비 시에는 중소과를 선호하는 형태로 양분화 되는 추세이다 $(1,2)$. '한아름'은 국내에서는 약 $10 \mathrm{ha}$ 가 재배되고 있으며, 8월 중순에 성숙 하는 첫배로 1988년 '신고'와 ‘추황배'를 교배하여 국립원 
예특작과학원에서 육성한 과중 $480 \mathrm{~g}$ 전후의 중소과 품종 이다. 가용성고형물이 $13.8{ }^{\circ} \mathrm{Brix}$ 로 높고, 산미가 적어 식미 가 우수하지만 상온 보구력은 7-10일 정도로 짧다(3). 그러 나, 조생종인 ‘원황’보다 수확시기가 빨라 여름 단경기 소비 수요를 충족시키고 고당도 과실을 원하는 국제시장에도 기대가 되는 품종이다(4). Kim 등(5)은 일반적으로 조생종 배는 중만생종에 비해 보구력이 짧고 수확하는 시기가 과실 의 수확 후 품질과 저장성에 더 많은 영향을 끼침으로 수확 시기에 대한 정밀한 검토가 필요하다고 하였다.

과실이 성숙함에 따라 물리적, 화학적으로 변화가 진행 되어 에틸렌 발생량, 과피색, 과육의 경도, 과육 성분, 과실 의 호흡량 등이 달라진다. 과실의 호흡량 증가는 체내 대사 작용을 촉진하고 에틸렌 발생을 증가시켜 노화를 촉진한다 (6). 동양배 중 ‘장십랑'은 호흡급등형을, '신고'는 비급등형 을 보여 품종별 수확 조만성에 따라 호흡형이 다르게 나타 나는 것으로 보고되고 있다(7). 배의 단맛을 내는 주요 가용 성 당은 fructose, glucose, sucrose, sorbitol로서 주요 당은 품종에 따라 다르다. Hong 등(8)은 '신수'는 과실이 성숙되 면 fructose와 sorbitol이 '행수'는 fructose와 sucrose가 주요 당이 되며 sucrose의 축적이 급격히 이루어지면서 전분이 완전히 소실되어 invertase의 활성이 급격히 저하하는 시기 를 수확적기라고 하였다.

과실 성숙기의 판단은 일반적으로 과피색, 과육의 경도, 과육 성분변화, 과실의 호흡량, 개화 후 일수, 적산온도 등을 복합적으로 고려하여 판단하고 있으나 보다 용이하게 숙기 를 판단할 수 있는 지표를 필요로 하고 있다. 특히, 특히, 나주에서 8월 15-20일에 수확하고 있는 한아름은 생육단계 별로 과실의 품질이 어떻게 변화하는지에 대한 종합적인 정보가 아직은 부족하다. 따라서, 본 연구는 '한아름'의 생육시기별 과실의 발육 및 물리 화학적 특성과 당 축적 패턴 등을 비교 분석함으로써 합리적인 수확 기준의 지표를 제시하고자 수행하였다.

\section{재료 및 방법}

\section{실험재료}

배연구소(전남 나주시 금천면 소재) 내 $\mathrm{Y}$ 자 수형으로 재식된 8년생 '한아름' 10주를 대상으로 2014년 만개 후 54 일(6월 5일)부터 만개 후 130일(8월 20일)까지 유과기에 는 2 주, 성숙기에는 5 일 간격으로 과실을 수확하였다. 시험 수는 미국수출용(PB1, 농협아그로) 봉지를 씨워 관행 재배 하였으며, 모든 시기별 수체의 중간부에서 10 개의 과실을 수확하여 실험에 사용하였다.

\section{품질조사}

수확한 과실의 과중은 전자저울(ELT-4001, Sartorius Co.,
Ltd., Goettingen, Germany)로 측정하였고 수확 후 과실의 종경(length)과 횡경(diameter)을 vernier calipers (500-196-30, Mitutoyo Co. Ltd., Kawasaki, Japan)로 측정한 값을 L/D ratio 로 나타냈다. 과실의 경도는 경도계(FT-327 penetrometer, Wagner instruments., Greenwich, USA)로 직경 $8 \mathrm{~mm}$ probe 를 이용하여 과피를 제거한 과실 적도면의 최대압력을 측정 하였다. 과피색은 색차계(CR-300, Konica Minolta, Inc., Tokyo, Japan)를 이용하여 각 개체의 모든 과실의 적도면을 측정하여 Hunter 명도 (L), 적색도 (a), 황색도 (b)를 측정하 였다. 가용성 고형물의 함량은 과실의 적도면과 수직으로 절단하여 얻은 조각을 이용하여 과즙을 착즙한 후 digital refractometer (PR-32a, ATAGO Co., Ltd., Tokyo, Japan)를 사용하여 측정하였다. 산 함량은 가용성고형물 함량 측정 을 위해 과즙을 채취한 방법과 동일하게 착즙한 후 $5 \mathrm{~mL}$ 를 증류수 $20 \mathrm{~mL}$ 에 희석하여 $0.1 \mathrm{~N} \mathrm{NaOH}$ 를 이용하여 $\mathrm{pH}$ 8.1 까지 중화 적정한 후 사과산으로 환산하였다. 과실의 전분함량 변화는 과실 내 녹말이 요오드 용액과 반응하면 청색으로 변하는 원리를 이용하였다(9). 절단한 과육 전면 에 $1 \%$ 요오드 용액을 바르고 반응 30 분 후 색차계로 과육색 을 측정하고, 명도(L) 값으로 나타냈다(10). 과육 내 축적된 유리당은 high performance liquid chromatography (HPLC, Nexera X2, Shimadzu Corp., Kyoto, Japan)를 이용하여 분석 하였다. 착즙한 과즙은 원심분리기(Avanti J-E, Beckman Coulter Inc., Deutschland, Germany)로 상등액을 취하고 $0.45 \mu \mathrm{m}$ membrane syringe filter (Whatman Inc., Maidstone, Kent, UK)로 분리정제 하였다. 당분석 전용 칼럼인 sugar pak I $(6.5 \times 300 \mathrm{~mm}$, Waters Corp., Milford, MA, USA)을 이용하여 물질을 분리하였고, 이동상은 $\mathrm{ddH}_{2} \mathrm{O}$ 를 등용매한 조건으로 $85^{\circ} \mathrm{C}$ 에서 유속 $0.5 \mathrm{~mL} / \mathrm{min}$ 로 흘려주었으며, refractive index detector (RID 10A, Shimadzu Corp.)를 이용 하여 검출하였다. 분리된 유리당은 sucrose, glucose, fructose, sorbitol (Sigma Chemical Co., St. Louis, Mo, USA) 등의 standard와 retention time, spectrum을 비교하고 spike test를 실시하였다.

\section{기상자료 분석}

2014년 한아름의 만개일부터 생육기간 동안(4-8월)의 기 후는 기상청에서 제공한 자동기상관측장치(AWS)로 수집 된 기상자료(www.kma.go.kr)를 이용하였다. 전남 나주시 금천면의 기후조건은 최저 평균온도 $15.8^{\circ} \mathrm{C}$, 최고 평균온도 $26.0^{\circ} \mathrm{C}$, 평균 기온 $20.7^{\circ} \mathrm{C}$, 누적 강수량은 $713 \mathrm{~mm}$ 이었다. 또한 개화기를 기준으로 수확한 기간까지의 적산온도를 나타내었다(Table 1).

\section{통 계}

성숙기를 결정하는 중요 지표를 검토하기 위해 수집된 데이터 중 11 개 형질은 $\mathrm{R}$ 통계 프로그램(R ver. 2.14.1, 
Newzeland)을 이용하여 Pearson 상관 계수를 이용한 상관 분석과 평균간 유의차 $95 \%$ 수준에서 Duncan's multiple range test를 실시하였다.

\section{결과 및 고찰}

\section{한아름의 적숙기 판정}

만개 후 54일부터 수확한 '한아름'의 과실의 과중은 만개 후 96 일부터 115 일에는 과중이 급격히 증가하였고 그 이후 다소 완만해졌다(Table 2). 종경(L)과 횡경(D)도 유사한 경 향을 보였는데 만개 후 110 일 이후부터 과실의 길이 생장은 완만해지고 과실 폭의 증가가 두드러졌다. 조생종인 '한아 름'은 만개 후 40 일까지 세포분열 및 비대에 의해 종, 횡축의 과실 비대가 함께 진행되나, 이후에는 세포비대에 의해서 횡축으로 더 많은 과실비대가 이루어지므로(11) L/D ratio 는 만개 후 96 일까지는 0.9 , 만개 후 110 일 이후에는 0.87 -
0.89 로 원형에 가까운 편원형으로 성숙기까지 유지되며 한 아름 고유 특성을 보였다. Ribeiro 등(12)이 과육의 경도는 세포벽이 외압에 견디는 힘에 의해 결정되며 과즙량, 가용 성 고형물, 향기 등과 부의 상관을 보여준다고 보고한 것처 럼 과육의 경도는 과실의 성숙도 또는 상온 보구력 평가의 중요 지표로 사용되고 있다. 따라서, 과실 발육 단계별로 과실의 경도를 분석하였다. 만개 후 82 일의 과육경도는 $11.5 \mathrm{~kg} / 8 \mathrm{~mm} \Phi$ 이었으나 과실 발육이 진행되는 생육기간 중 꾸준히 감소하여 만개 후 115 일에는 $3.6 \mathrm{~kg} / 8 \mathrm{~mm} \Phi$ 수준 으로 만개 후 125 일과 130 일의 경도와 유의차가 없었다. 다만, 만개 후 115 일 과실은 가식해도 큰 무리가 없을 정도 로 과육의 연화는 상당히 진전되었으나 먹었을 때 전분이 많이 느껴져 식미는 좋지 않았다(data not shown). 전체 가용 성 고형물 및 산 함량은 만개 후 82 일 이후부터는 유의한 차이가 없었다. 과실 내 전분 축적 패턴 관찰을 위해 요오드 화 반응 실시 후 과육색의 $\mathrm{L}$ 값을 측정하였다. 요오드화 반응은 전분의 함량이 많을수록 짙고 어두운 색을 띄며

Table 1. Monthly trend of the temperature, precipitation and accumulated temperature in Naju (2014)

\begin{tabular}{|c|c|c|c|c|c|c|}
\hline \multicolumn{2}{|c|}{ Month Climate } & Apr. & May & June & July & Aug. \\
\hline \multirow{2}{*}{$\begin{array}{l}\text { Temperature } \\
\left({ }^{\circ} \mathrm{C}\right)\end{array}$} & Highest & 20.7 & 24.7 & 27.9 & 28.9 & 27.7 \\
\hline & Lowest & 7.9 & 10.7 & 18.5 & 20.9 & 21.0 \\
\hline \multicolumn{2}{|c|}{ Precipitation (mm) } & 62.5 & 57.0 & 72.0 & 239.4 & 282.2 \\
\hline \multicolumn{2}{|c|}{$\mathrm{DAFB}^{1)}$} & 54 & 82 & 110 & 119 & 130 \\
\hline \multicolumn{2}{|c|}{$\begin{array}{c}\text { Accumulated temperature } \\
\left({ }^{\circ} \mathrm{C}\right)\end{array}$} & 901.4 & 1535.2 & 2238.5 & 2461.1 & 2698.9 \\
\hline
\end{tabular}

${ }^{11}$ Days after full bloom, From 54 DAFB to 130 DAFB. 'Hanareum' was harvested in 82 days after full bloom (DAFB, June $5^{\text {th }}$ ), 96 DAFB (June $19^{\text {th }}$ ), 110 DAFB (July $3^{\text {th }}$ ), 115 DAFB (July $17^{\text {th }}$ ), 119 DAFB (August $5^{\text {th }}$ ), 125 DAFB (August $9^{\text {th }}$ ), 130 DAFB (August $15^{\text {th }}$ ), 135 DAFB (August $20^{\text {th }}$ ).

${ }^{2)}$ Accumulated temperature was calculated by month averaged temperature from June $5^{\text {th }}$ to August $20^{\text {th }}$.

Table 2. Change of fruit characteristics during fruit development of 'Hanareum' pear ( $P$. pyrifolia Nakai) in 2014

\begin{tabular}{cccccccccc}
\hline $\begin{array}{c}\text { Harvest } \\
\left(\mathrm{DAFB}{ }^{1}\right)\end{array}$ & $\begin{array}{c}\text { Fruit } \\
\text { weight(g) }\end{array}$ & L/D ratio & $\begin{array}{c}\text { Flesh hardness } \\
(\mathrm{Kg} / 8 \mathrm{~mm} \Phi)\end{array}$ & $\begin{array}{c}\text { Soluble solids } \\
\left({ }^{\circ} \mathrm{Bx}\right)\end{array}$ & $\begin{array}{c}\text { Acidity } \\
(\%)\end{array}$ & $\begin{array}{c}\text { Iodine test } \\
\left.\mathrm{L}^{2}\right)^{2}\end{array}$ & \multicolumn{3}{c}{ Fruit skin chromaticity $^{3)}$} \\
\hline 54 & $20 \pm 1^{\left.4) g^{2}\right)}$ & $0.96 \pm 0.02$ & $\mathrm{ND}^{6}$ & $7.5 \pm 0.1^{\mathrm{d}}$ & $\mathrm{ND}$ & $\mathrm{ND}$ & $57.6 \pm 1.6^{\mathrm{d}}$ & $-17.1 \pm 0.9^{\mathrm{g}}$ & $38.1 \pm 1.2^{\mathrm{a}}$ \\
68 & $40 \pm 1^{\mathrm{g}}$ & $0.92 \pm 0.02$ & $\mathrm{ND}$ & $8.3 \pm 0.1^{\mathrm{c}}$ & $\mathrm{ND}$ & $\mathrm{ND}$ & $55.3 \pm 1.3^{\mathrm{e}}$ & $-12.5 \pm 1.1^{\mathrm{f}}$ & $38.5 \pm 1.6^{\mathrm{a}}$ \\
82 & $79 \pm 3^{\mathrm{f}}$ & $0.90 \pm 0.01$ & $11.5 \pm 0.1^{\mathrm{a}}$ & $11.7 \pm 0.2^{\mathrm{b}}$ & $0.26 \pm 0.01^{\mathrm{a}}$ & $23.9 \pm 0.4^{\mathrm{d}}$ & $58.7 \pm 1.6^{\mathrm{d}}$ & $-9.4 \pm 1.2^{\mathrm{e}}$ & $33.5 \pm 1.2^{\mathrm{c}}$ \\
96 & $173 \pm 4^{\mathrm{e}}$ & $0.90 \pm 0.01$ & $8.1 \pm 0.6^{\mathrm{b}}$ & $11.7 \pm 0.3^{\mathrm{b}}$ & $0.13 \pm 0.01^{\mathrm{b}}$ & $28.0 \pm 1.1^{\mathrm{d}}$ & $58.9 \pm 1.7^{\mathrm{d}}$ & $-7.9 \pm 1.8^{\mathrm{d}}$ & $35.4 \pm 0.9^{\mathrm{b}}$ \\
110 & $322 \pm 7^{\mathrm{d}}$ & $0.87 \pm 0.02$ & $4.2 \pm 0.2^{\mathrm{c}}$ & $12.2 \pm 0.2^{\mathrm{b}}$ & $0.11 \pm 0.01^{\mathrm{b}}$ & $43.6 \pm 0.8^{\mathrm{c}}$ & $61.9 \pm 2.2^{\mathrm{c}}$ & $-4.0 \pm 1.0^{\mathrm{c}}$ & $38.9 \pm 0.4^{\mathrm{a}}$ \\
115 & $411 \pm 5^{\mathrm{c}}$ & $0.88 \pm 0.02$ & $3.6 \pm 0.2^{\text {cd }}$ & $11.8 \pm 0.1^{\mathrm{b}}$ & $0.12 \pm 0.01^{\mathrm{b}}$ & $45.7 \pm 2.5^{\mathrm{c}}$ & $62.6 \pm 1.8^{\mathrm{bc}}$ & $-3.4 \pm 0.8^{\mathrm{c}}$ & $38.3 \pm 1.2^{\mathrm{a}}$ \\
119 & $454 \pm 19^{\mathrm{b}}$ & $0.88 \pm 0.03$ & $3.6 \pm 0.4^{\mathrm{cd}}$ & $11.9 \pm 0.2^{\mathrm{b}}$ & $0.11 \pm 0.00^{\mathrm{b}}$ & $46.2 \pm 0.6^{\mathrm{c}}$ & $63.7 \pm 1.5^{\mathrm{abc}}$ & $-0.9 \pm 1.4^{\mathrm{b}}$ & $37.7 \pm 2.1^{\mathrm{a}}$ \\
125 & $546 \pm 19^{\mathrm{a}}$ & $0.89 \pm 0.02$ & $3.4 \pm 0.1^{\mathrm{cd}}$ & $11.9 \pm 0.2^{\mathrm{b}}$ & $0.11 \pm 0.00^{\mathrm{b}}$ & $54.6 \pm 2.9^{\mathrm{b}}$ & $65.0 \pm 2.3^{\mathrm{a}}$ & $-2.8 \pm 2.0^{\mathrm{c}}$ & $37.9 \pm 1.3^{\mathrm{a}}$ \\
130 & $551 \pm 9^{\mathrm{a}}$ & $0.87 \pm 0.02$ & $3.2 \pm 0.1^{\mathrm{d}}$ & $12.3 \pm 0.1^{\mathrm{a}}$ & $0.12 \pm 0.00^{\mathrm{b}}$ & $62.7 \pm 1.6^{\mathrm{a}}$ & $64.4 \pm 1.1^{\mathrm{ab}}$ & $-0.3 \pm 1.3^{\mathrm{b}}$ & $37.9 \pm 0.8^{\mathrm{a}}$ \\
\hline
\end{tabular}

\footnotetext{
${ }^{1)}$ Fruits were harvested on the days after full bloom (DAFB).

${ }^{2)} \mathrm{L}$, lightness of flesh color after iodine spray.

${ }^{3)}$ Chromaticity, L(lightness:0-100); a (green -60-red 60); b (blue - 60-yellow 60).

${ }^{4}$ Means \pm SE $(\mathrm{n}=10)$.

5):- Different superscripts in the same column are significantly different at $p<0.05$ by Duncan's multiple range test.

${ }^{6} \mathrm{ND}$, no data.
} 
L값이 낮은 경향을 보인다. 만개 후 82 일은 요오드 반응 후 과육색이 검게 변하여 L 값이 23.9로 매우 낮았다. 만개 후 110 일 부터는 L 값이 $43.6,125$ 일에는 54.6으로 유의하게 상승하여 과실 발육이 진행됨에 따라 전분이 감소함을 확인 할 수 있었다. 즉, 유과기에는 과실에 전분 중심으로 축적되 다가 만개 후 119 일에는 과심주변 중심으로 전분이 사라지 며 만개 후 125 일 이후에는 과실 내 전분이 완전히 사라졌다 (Fig. 1). 과실의 과피색은 과실 발육 및 성숙이 진행됨에 따라 명도(L) 값이 57.6에서 64.4로 증가하고 적색도(a)는 -17.1 에서 -0.3 으로 증가하였으나 황색도(b)는 38.1에서 37.9로 큰 차이 없이 유지되었다. 적색도(a)의 증가는 녹색 에서 적색으로의 변화를 의미하며 이는 코르크층의 발달 및 착색 등으로 생장 초기 과피 내에 존재하는 클로로필이 가려지는 과피의 성숙과 수반되는 현상을 의미하는 것으로
생각할 수 있다.

과실의 발육 시기별로 채취한 과즙을 $\mathrm{HPLC}$ 로 분석한 결과, 유리당 조성의 비율이 달라졌다(Table 3). 만개 후 54 일의 $20 \mathrm{~g}$ 크기 유과는 sorbitol이 유리당의 $87 \%$ 인 40.6 $\mathrm{mg} / \mathrm{mL}$ 이었고, sucrose, glucose, fructose의 함량은 미미하 였다. 과실 발육이 진행됨에 따라 sucrose는 만개 후 130 일 까지 지속적으로 증가한 반면 fructose는 만개 후 110 일부터 감소하였다. Sorbitol은 배를 포함한 장미과 식물의 성숙 엽에서 합성되어 과실로 전이되며 fructose로 분해되는 특 징을 갖고 있어 성숙기가 진전됨에 따라 총 함량이 감소하 게 된다(13). '한아름‘도 시기별로 sorbitol의 감소와 fructose 의 증가가 관련이 있음을 보여주었는데 만개 후 110 일은 fructose가 $44 \%$ 인 $53.9 \mathrm{mg} / \mathrm{mL}$ 로 최대치에 도달한 후 서서 히 감소하였다. sucrose는 만개 후 110 일부터 급증하여 만개
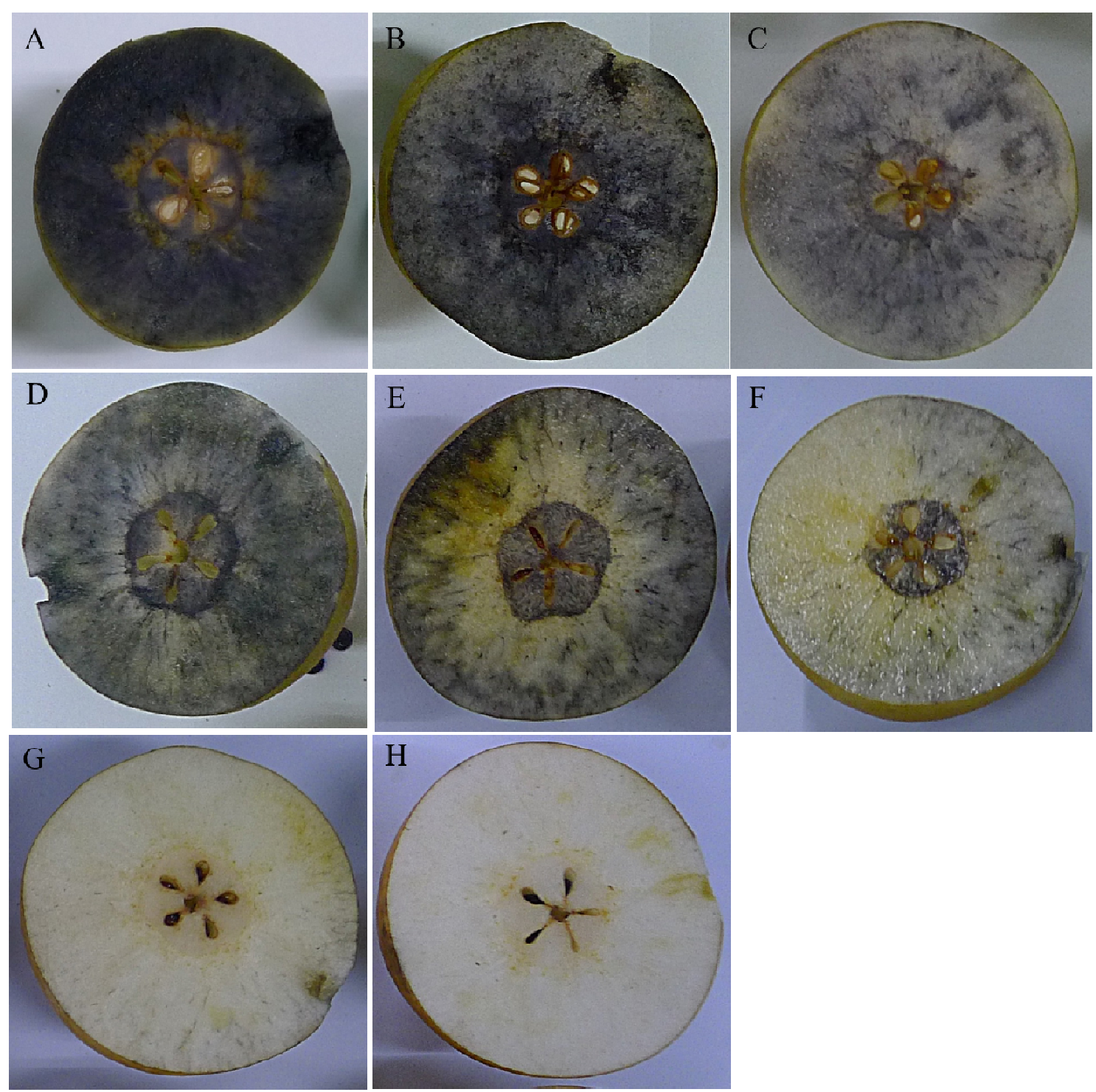

Fig. 1. Change of flesh color after iodine test during fruit development of 'Hanareum' pear in 2014.

A, 82 days after full bloom (DAFB); B, 96 DAFB; C, 110 DAFB; D, 115 DAFB; E, 119 DAFB; F, 125 DAFB; G, 130 DAFB; H, 135 DAFB. 
Table 3. Change of soluble sugar composition during fruit development in 'Hanareum' pears in 2014.

\begin{tabular}{|c|c|c|c|c|c|c|}
\hline \multirow{2}{*}{$\begin{array}{l}\text { Harvest } \\
\left(\text { DAFB }^{1}\right)\end{array}$} & \multicolumn{4}{|c|}{ Free sugar contents $(\mathrm{mg} / \mathrm{mL})$} & \multirow{2}{*}{ Total } & \multirow{2}{*}{$\mathrm{S} / \mathrm{F}$ ratio } \\
\hline & Sucrose & Glucose & Fructose & Sorbitol & & \\
\hline 54 & $0.0 \pm 0.0^{2) \mathrm{d} 3)}$ & $2.9 \pm 0.8^{\mathrm{e}}$ & $3.0 \pm 0.2^{\mathrm{f}}$ & $40.6 \pm 0.6^{c}$ & 46.4 & 0.0 \\
\hline 68 & $0.0 \pm 0.0^{\mathrm{d}}$ & $8.3 \pm 0.6^{\text {cd }}$ & $13.6 \pm 1.4^{e}$ & $53.6 \pm 0.9^{b}$ & 75.5 & 0.0 \\
\hline 82 & $1.4 \pm 0.6^{\mathrm{d}}$ & $15.5 \pm 0.7^{\mathrm{b}}$ & $33.0 \pm 1.9^{\mathrm{d}}$ & $66.3 \pm 1.5^{\mathrm{a}}$ & 116.2 & 0.0 \\
\hline 96 & $0.0 \pm 0.0^{\mathrm{d}}$ & $20.8 \pm 1.4^{\mathrm{a}}$ & $47.9 \pm 2.1^{\mathrm{bc}}$ & $40.3 \pm 1.2^{c}$ & 109.0 & 0.0 \\
\hline 110 & $21.9 \pm 2.7^{\mathrm{c}}$ & $17.1 \pm 1.5^{b}$ & $53.9 \pm 1.8^{\mathrm{a}}$ & $30.9 \pm 1.1^{\mathrm{d}}$ & 123.8 & 0.4 \\
\hline 115 & $27.3 \pm 2.9^{c}$ & $16.0 \pm 1.1^{\mathrm{b}}$ & $50.9 \pm 1.3^{\mathrm{ab}}$ & $21.7 \pm 1.0^{\mathrm{e}}$ & 115.9 & 0.5 \\
\hline 119 & $40.0 \pm 3.2^{b}$ & $10.5 \pm 0.8^{c}$ & $42.3 \pm 1.5^{\mathrm{c}}$ & $19.1 \pm 0.5^{\mathrm{e}}$ & 111.9 & 0.9 \\
\hline 125 & $46.6 \pm 4.1^{b}$ & $10.3 \pm 1.1^{\mathrm{c}}$ & $43.2 \pm 2.5^{\mathrm{c}}$ & $15.0 \pm 1.2^{\mathrm{f}}$ & 115.1 & 1.1 \\
\hline 130 & $59.7 \pm 7.0^{\mathrm{a}}$ & $6.3 \pm 1.1^{\mathrm{de}}$ & $35.5 \pm 4.7^{\mathrm{d}}$ & $11.5 \pm 1.6^{\mathrm{g}}$ & 112.9 & 1.7 \\
\hline
\end{tabular}

${ }^{1)}$ Days after full bloom.

${ }^{2)}$ Means \pm SE $(\mathrm{n}=10)$

3)a-fDifferent superscripts in the same column are significantly different at $\mathrm{p}<0.05$ by Duncan's multiple range test.

후 130 일에는 $59.7 \mathrm{mg} / \mathrm{mL}$ 에 달했다. Yamaki 와 Takaya (14)는 발육시기별 '행수'의 과실 내 당 축적 변화는 유과기 에 sorbitolo이 총 당의 $70 \%$ 이상을 차지하여 높게 유지되다 가 성숙기에 이르면 fructose와 sucrose의 함량이 급속히 증가한다고 하였고 본 연구에서의 '한아름'도 과실 발육 단계에 따라 유사한 경향을 보였다.

따라서 한아름의 성숙기 결정을 위해 조사하였던 과중, 과육 경도, 요오드 변색에 의한 전분함량의 정도, 당 조성 변화 등을 종합하여 '한아름'은 만개 후 125 일을 생리적 성숙기로, 전분은 다소 남아있지만 과육의 경도가 생리적 성숙기와 유사하게 연화되는 만개 후 119 일을 원예적 성숙 기로 추정해 볼 수 있을 것으로 판단되었다(Fig. 2).

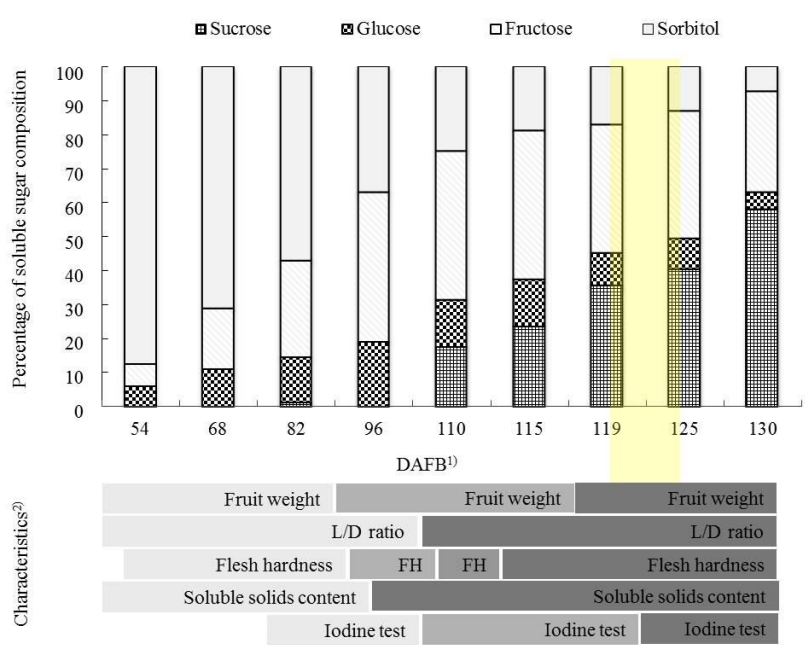

Fig. 2. The scheme of ripening time decision based on the soluble sugar composition and fruit physical characteristics by fruit development period.

${ }^{1}$ DAFB, days after full bloom.

${ }^{2}$ Each graded gray color means grouped fruit characteristics by fruit development status based on statistic significance.

${ }^{3}$ Yellow square means physiological ripening time.

\section{성숙기 판정지표}

수확시기의 결정은 조사자의 주관 또는 감각에 의존하는 경우가 많기 때문에 ‘한아름' 과실의 성숙기를 객관적으로 판단할 수 있는 지표를 탐색하기 위해 생육시기별 과실의 발육 특성과 당 조성 변화 패턴과의 상관을 분석 하였다 (Table 4). 당 조성 성분 중 sucrose는 과중과는 $\mathrm{r}=0.72$, 요오 드 반응에 의한 과육의 명도(L) 값과는 $\mathrm{r}=0.80$, sorbitol과 과육경도는 $\mathrm{r}=0.96$ 으로 양의 상관관계를 보였다( $\mathrm{p}<0.001)$. 이는 과실의 성숙과 과실 내부의 당 조성 변화가 밀접한 관계가 있음을 보여주는 결과로 Matsumoto 등(15)이 환원 당 축적형 포도의 경우, 성숙이 가까워질수록 당 조성 비율 의 차이가 크게 나타나므로 당 성분 변화를 기준으로 출하 시기 판단 및 정확한 품질 평가의 수단으로 활용할 수 있을 것으로 보고하였다. Fawole과 Opara(16)도 석류의 당 조성 분석 후 주 당을 차지하는 glucose와 fructose의 비율이 0.67-0.85 일 때를 성숙기 판단 기준으로 활용할 수 있음을 보고한 바 있어 '한아름'의 성숙기 판단에 당 조성의 변화의 이용이 가능할 것으로 생각되었다.

'한아름'의 sucrose/fructose (S/F) 비율이 유과일 때는 0에 가까운 값을 보이다가 과실이 발육하는 동안 점점 증가하여 성숙기인 만개 후 119-125일 무렵에는 0.9-1.1 수준을 보이 며 만개 후 130 일에는 $\mathrm{S} / \mathrm{F}$ 비율이 꾸준히 증가하여 1.7 에 도달하였다. 또한, 과실의 중요 성숙 지표인 경도와 $\mathrm{S} / \mathrm{F}$ 비율은 $\mathrm{r}=-0.57$ 로 강한 음의 상관관계를, Iodine test 결과와 는 $\mathrm{r}=0.80$ 으로 강한 양의 상관관계를 보였다 $(\mathrm{p}<0.001)$. Oanh 등(17)은 '한아름'의 성숙 기간 중 당 조성과 세포벽 물질 변화를 조사결과 만개 후 120 일에 수확한 과실의 $\mathrm{S} / \mathrm{F}$ 비율이 0.8 로 1 에 가까워진다고 보고하였는데 본 시험에서 도 만개 후 119 일에 $\mathrm{S} / \mathrm{F}$ 비율이 0.9 로 유사한 결과를 보여주 었다. 추후 과실의 숙도를 추정하거나 시료의 발육단계를 일치시켜 비교하고자 할 때 $\mathrm{S} / \mathrm{F}$ 비율을 이용하면 분석시료 
Table 4. Pearson correlations coefficients among physicochemical characteristics.

\begin{tabular}{|c|c|c|c|c|c|c|c|c|c|c|c|}
\hline & $\begin{array}{l}\text { Fruit } \\
\text { weight }\end{array}$ & $\mathrm{L} / \mathrm{D}$ & $\begin{array}{c}\text { Flesh } \\
\text { hardness }\end{array}$ & $\begin{array}{l}\text { Iodione } \\
\text { test L }\end{array}$ & $\begin{array}{l}\text { Soluble solids } \\
\text { contents }\end{array}$ & Sucrose & Glucose & Fructose & Sorbitol & $\begin{array}{l}\text { Sucrose/ } \\
\text { Glucose }\end{array}$ & $\begin{array}{l}\text { Sucrose/ } \\
\text { Sorbitol }\end{array}$ \\
\hline Fruit weight & 1.00 & & & & & & & & & & \\
\hline L/D & $-0.34^{*}$ & 1.00 & & & & & & & & & \\
\hline Flesh hardness & $-0.90^{* * *}$ & $0.17^{\mathrm{ns}}$ & 1.00 & & & & & & & & \\
\hline Iodione test $\mathrm{L}$ & $0.92^{* * *}$ & $-0.26^{\mathrm{ns}}$ & $-0.83^{* \star *}$ & 1.00 & & & & & & & \\
\hline Soluble solids & $0.27^{\mathrm{ns}}$ & $-0.31^{\mathrm{ns}}$ & $-0.09^{\mathrm{ns}}$ & $0.38^{*}$ & 1.00 & & & & & & \\
\hline Sucrose & $0.72^{* * *}$ & $-0.24^{\mathrm{ns}}$ & $-0.56^{* * *}$ & $0.80^{* * *}$ & $0.58^{* * *}$ & 1.00 & & & & & \\
\hline Glucose & $-0.58^{* * *}$ & $0.20^{\mathrm{ns}}$ & $0.43^{* *}$ & $-0.51^{* *}$ & $-0.10^{\mathrm{ns}}$ & $-0.64^{* * *}$ & 1.00 & & & & \\
\hline Fructose & $0.42^{*}$ & $-0.12^{\mathrm{ns}}$ & $-0.52^{* \star}$ & $0.48^{* *}$ & $0.31^{\mathrm{ns}}$ & $0.43^{* *}$ & $0.27^{\mathrm{ns}}$ & 1.00 & & & \\
\hline Sorbitol & $-0.95^{* * *}$ & $0.34^{*}$ & $0.96^{* * *}$ & $-0.88^{* * *}$ & $-0.28^{\text {ns }}$ & $-0.65^{* k *}$ & $0.46^{* *}$ & $-0.51^{* *}$ & 1.00 & & \\
\hline Sucrose/Glucose & $0.62^{* * *}$ & $-0.12^{\mathrm{ns}}$ & $-0.44^{* *}$ & $0.69^{* * *}$ & $0.55^{* * *}$ & $0.93^{* * *}$ & $-0.66^{* * *}$ & $0.25^{\mathrm{ns}}$ & $-0.55^{* * *}$ & 1.00 & \\
\hline Sucrose/Fructose & $0.76^{* * *}$ & $-0.24^{\mathrm{ns}}$ & $-0.57^{* * *}$ & $0.80^{* * *}$ & $0.56^{* * *}$ & $0.97^{* * *}$ & $-0.72^{* * *}$ & $0.30^{\mathrm{ns}}$ & $-0.68^{* * *}$ & $0.95^{* * *}$ & 1.00 \\
\hline Sucrose/Sorbitol & $0.60^{* * *}$ & $-0.08^{\mathrm{ns}}$ & $-0.46^{* *}$ & $0.68^{* * *}$ & $0.46^{* *}$ & $0.93^{* * *}$ & $-0.60^{* * *}$ & $0.23^{\mathrm{ns}}$ & $-0.54^{* * *}$ & $0.98^{* * *}$ & $0.94^{* * *}$ \\
\hline
\end{tabular}

\section{요 약}

본 연구는 ‘한아름'의 생육시기별 과실의 발육 및 물리 화학적 특성과 당 축적 패턴 등을 비교 분석함으로써 합리 적인 수확 기준의 지표를 제시하고자 만개 후 54일부터 2주 간격으로 수확한 '한아름'의 과실특성을 평가하였다. 그 결과, 과중은 만개 후 96 일부터 115 일까지 급격하게 증 가하였고, 그 이후로는 완만해져 전형적인 sigmoidal curve 를 보였다. 과육의 경도는 만개 후 96 일 이후 꾸준히 감소하 여 만개 후 115 일에는 125 일과 130 일의 경도와 유의차가 없었다. sucrose와 fructose는 과실 발육이 진전됨에 따라 증가하는 경향을 보였는데 만개 후 130 일 까지 sucrose는 지속적으로 증가한 반면 fructose는 만개 후 110 일부터 감소 하였다. 전분은 만개 후 119 일부터 과심 주변에서부터 사라 지기 시작하여 만개 후 125 일, 130 일에는 요오드 반응에 의한 변색이 일어나지 않았다. 이와 같은 결과를 바탕으로 ‘한아름'의 생리적 성숙기는 만개 후 119 일인 것으로 추정 하였다. '한아름'의 생육시기별 과실의 발육 특성과 당 조성 변화를 상관분석 한 결과, 과중은 요오드 반응 후의 $\mathrm{L}$ 값과 sucrose 함량이, 그리고 과육경도는 sorbitol과 고도의 양적 선형관계를 보였다. 특히, sucrose/fructose $(\mathrm{S} / \mathrm{F})$ 비율은 과육 경도와 -0.57 , iodine test 결과와는 0.80 으로 높은 양의 상관 을 보여주어 S/F 비율이 0.9-1.1 수준을 보이는 시기는 생리 적 성숙기인 것으로 추정할 수 있을 것으로 판단되었다.
본 연구는 농촌진흥청 기본연구사업(PJ00689403)의 지 원에 의해 수행되었으며 이에 감사드립니다.

\section{References}

1. Korea Rural Economic Institute (2017) Agricultural prospective. D\&C Co, Daejeon, Korea, 2, 483-488

2. Park YS, Kwon YH (2014) Criteria of fruit quality and harvest for production of high quality small and medium-sized fruits in 'Hanareum' pear (Pyrus pyrifolia Nakai). Protected Hort Plant Fac, 23, 131-138

3. Hwang HS, Shin IS, Kim WC, Shin YU, Hwang JH, Hong SS (2005) Breeding of a good quality, large size, and early summer season pear cultivar 'Hanareum' (Pyrus pyrifolia Nakai). Kor J Hort Sci Technol, 23, 60-63

4. Lee UY, Hwang YS, YJ Ahn, JP Chun (2013) Comparison of fruit quality and occurrence of physiological disorders during storage and simulated marketing at different temperature conditions in 'Hanareum' pears. Korean J Agric Sci, 40, 191-196

5. Kim MS, Cho KS, Hong SJ (2003) Determination of optimum harvest time of 'Geumchonjosaeng' pear (Pyrus pyrifolia) and its shelf life at ambient temperature. Kor J Hort Sci Technol, 21, 120-123

6. Kader AA (1989) Mode of action of oxygen and carbon dioxide on postharvest physiology of 'Bartlett' pears. 
Acta Hortic, 258, 161-167

7. Jeong ST, Kim JG, Hong SS, Jang HS, Kim YB (1998) Influence of maturity and storage temperature on the respiration rate and ethylene production in 'Kosui', 'Chojuro' and 'Niitaka' pears. Kor J Hort Sci Technol, 39, 446-448

8. Hong SJ, Kim MS, Park SW, Shin IS (1998) Changes in contents of soluble sugars, organic acids, and the fruit taste of early season pear cultivars during maturation. Kor J Hort Sci Technol, 39, 408-411

9. Beattie BB, Wild BL (1973) Assessing harvest maturity of 'Granny Smith' apples for export. Agr Gaz New S Wales, 84, 30-33

10. Kim YK, SS Kang, KS Cho, JH Song, R. Sherzod, Choi HS (2013) Shelf-life comparison of 'Manpungbae' fruit between harvest time and fruit size under $20^{\circ} \mathrm{C}$. Korean J Intl Agri, 25, 68-72

11. Park JE, Kwon Y, Lee B, Park Y, Jung MH, Choi JH, Park HS. (2014) Anatomical structure and fruit quality according to the fruit sevelopmental stage as affected by gibberellins treatments in Pyrus pyrifolia Nakai cv. Hanareum. Kor J Hort Sci Technol, 32, 33-40

12. Ribeiro CJO, Cavalheiro JT, Santos ASA, Meireles O, Ponteira D (2008) Preliminary characterization of Portuguese pear cultivars after cold storage. Acta Hortic, 800, 1077-1084
13. Loescher WH (1987) Physiology and metabolism of sugar alcohols in higher plants. Physiol Plantarum, 70, 553-557

14. Yamaki S, Takaya M (1989) Seasonal fluctuation of sorbitol-related enzymes and invertase activities accompanying maturation of Japanese pear (Pyrus serotina Rehder var. culta Rehder) fruit. J Japan Soc Hort Sci, 57, 602-607

15. Matsumoto K, Kim BK, Oahn VTK, Seo JH, Yoon HK, Park MK, Hwang YS, Chun JP (2007) Comparison of sugar composition and quality parameters during berry ripening between grape cultivars. Kor J Hort Sci Technol, 25, 230-234

16. Fawole OA Opara UL (2013) Changes in physical properties, chemical and elemental composition and antioxidant capacity of pomegranate (cv. Ruby) fruit at five maturity stages. Sci Hortic, 150, 37-46

17. Oanh VTK, Lee UY, Choi JH, Lee HC, Chun JP (2012) Changes of fruit characteristics and cell wall component during maturation and ripening in Asian pear 'Hanareum', 'Manpungbae', and 'Niitaka'(Pyrus pyrifolia Nakai). Kor J Hort Sci Technol, 30, 345-356 